\title{
Coordination polymers undergoing spin crossover and reversible ligand exchange in the solid $\dagger$
}

\author{
Ana Galet, ${ }^{a}$ M. Carmen Muñoz ${ }^{a}$ and José Antonio Real*b \\ Received (in Cambridge, UK) 8th May 2006, Accepted 8th August 2006 \\ First published as an Advance Article on the web 6th September 2006 \\ DOI: $10.1039 / \mathrm{b} 606434 \mathrm{e}$
}

Here we report the synthesis and characterisation of a polymer made up of a system of parallel 2-D grids of $\mathrm{Fe}$ (II) ions linked by $\left[\mathrm{Au}(\mathrm{CN})_{2}\right]^{-}$bridges and its transformation into a new system of three interpenetrated 3-D coordination open frameworks with the $\mathrm{NbO}$ topology. Reversibility of this crystal-tocrystal transformation is evidenced by X-ray crystallographic data and from their spin crossover properties.

Implementation of coordination polymers ${ }^{1}$ with iron(II) spin crossover (SCO) building blocks ${ }^{2}$ is a singular approach to construct new advanced materials with potential applications. The SCO building blocks can be switched between the high- (HS) and low-spin (LS) states. This leads to distinctive changes in magnetism, colour and structure, which may be induced by a variation of temperature and/or pressure and by light irradiation. Strong signal generation and hysteresis (memory effect) may occur when rigid linkers, communicating between the SCO centres, propagate the structural changes cooperatively to the whole framework conferring a bistable character to the material. ${ }^{3}$ Furthermore, a synergy or interplay between the SCO and the inherent properties of the coordination polymer may be expected in favourable cases. This is particularly true when structural transformations are triggered by host-guest interactions for instance, ${ }^{1 c, 4}$ which have dramatic effects on the SCO properties. ${ }^{5}$

Herein we report the reversible structural transformation of a non porous 2-D SCO coordination polymer, $\{\mathrm{Fe}(3-$ $\left.\mathrm{CNpy})_{2}\left(\mathrm{CH}_{3} \mathrm{OH}\right)_{2 / 3}\left[\mathrm{Au}(\mathrm{CN})_{2}\right]_{2}\right\}$ (1) (3-CNpy = 3-CNpyridine) $;$ into a triple interpenetrated 3-D microporous $\mathrm{SCO}$ framework with the $\mathrm{NbO}$ structure type, $\left\{\mathrm{Fe}(3-\mathrm{CNpy})_{2}\left[\mathrm{Au}(\mathrm{CN})_{2}\right]_{2}\right\}$ (2). This is a new example of a crystalline-state ligand exchange reaction involving substitution-active iron(II) coordination sites able to selectively recognise guest $\mathrm{CH}_{3} \mathrm{OH}$ molecules. The effect of this transformation on the SCO properties is also investigated.

Compound 1 crystallizes in the triclinic $P \overline{1}$ space group. $\S$ There are three crystallographically independent $\mathrm{Fe}(\mathrm{II})$ atoms, each one lying on an inversion centre (Fig. 1, top). Sites $\mathrm{Fe}(1)$ and $\mathrm{Fe}(2)$ display strongly distorted $\left[\mathrm{FeN}_{6}\right]$ elongated octahedrons with the equatorial positions occupied by four $\left[\mathrm{Au}(\mathrm{CN})_{2}\right]^{-}$anions, which

${ }^{a}$ Departament de Física Aplicada, Universitat Politécnica de València, Camino de Vera s/n, 46022, Valencia, Spain.

E-mail: mcmunoz@fis.upv.es

${ }^{b}$ Instituto de Ciencia Molecular/Departamento de Química Inorgànica, Universitat de València, Edificio de Institutos de Paterna, P O Box 22085, 46071, València, Spain.E-mail: jose.a.real@uv.es;

Tel: 34963544856

$\uparrow$ Electronic supplementary information (ESI) available: Thermal analysis of 1; X-ray powder diffraction patterns of $\mathbf{1}$ and 2. See DOI: 10.1039/ b606434e
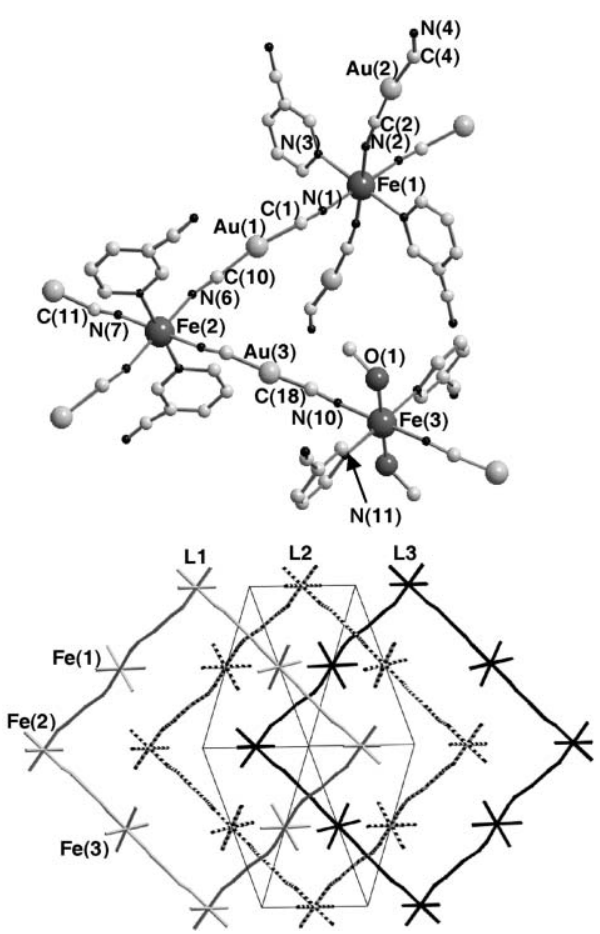

Fig. 1 Top: view of the asymmetric unit of the coordination polymer 1 displaying the corresponding atom numbering. Bottom: view of the relative disposition of three consecutive layers.

define the short $\mathrm{Fe}-\mathrm{N}$ distances $[\mathrm{Fe}(1)-\mathrm{N}(1)=2.13(6) \AA, \mathrm{Fe}(1)$ $\mathrm{N}(2)=2.16(6) \AA, \mathrm{Fe}(2)-\mathrm{N}(6)=2.09(7) \AA$ and $\mathrm{Fe}(2)-\mathrm{N}(7)=$ 2.19 (6) $\AA$ ], while the axial positions are occupied by the 3-CNpyridine ligands $[\mathrm{Fe}(1)-\mathrm{N}(3)=2.28(4) \AA$ and $\mathrm{Fe}(2)-\mathrm{N}(8)=$ 2.25(3) $\AA$. The $\mathrm{Fe}(3)$ site lies in a $\left[\mathrm{FeN}_{4} \mathrm{O}_{2}\right]$ compressed octahedron. The equatorial plane of the octahedron is defined by two 3-CNpy ligands $[\mathrm{Fe}(3)-\mathrm{N}(11)=2.22(3) \AA]$ and two $\left[\mathrm{Au}(\mathrm{CN})_{2}\right]^{-}$anions $[\mathrm{Fe}(3)-\mathrm{N}(10)=2.21(6) \AA]$. The axial positions are occupied by methanol molecules $[\mathrm{Fe}(3)-\mathrm{O}(1)=2.10(5) \AA]$.

There are also three crystallographically different $\left[\mathrm{Au}(\mathrm{CN})_{2}\right]^{-}$ groups: (i) $\left[\mathrm{Au}(1)(\mathrm{CN})_{2}\right]^{-}$bridges $\mathrm{Fe}(1)$ and $\mathrm{Fe}(2)$ sites, (ii) $\left[\mathrm{Au}(3)(\mathrm{CN})_{2}\right]^{-}$links $\mathrm{Fe}(2)$ and $\mathrm{Fe}(3)$ sites and (iii) $\left[\mathrm{Au}(2)(\mathrm{CN})_{2}\right]^{-}$ does not act as a bridging ligand. Consequently, the $\left[\mathrm{Au}(1)(\mathrm{CN})_{2}\right]^{-}$ and $\left[\mathrm{Au}(3)(\mathrm{CN})_{2}\right]^{-}$bridges meet at the $\mathrm{Fe}(2)$ atom, which constitute the nodes of a slightly corrugated 2-D grid defined by the sharing of $[\mathrm{Fe}(2)]_{4}$ rhombuses whose edges make 20.738(3) $\times$ 20.888(3) ^ (Fig. 1, bottom). The shortest and longest edges correspond to the connection of two $\mathrm{Fe}(2)$ sites through the $\mathrm{Fe}(1)$ and the $\mathrm{Fe}(3)$ atoms, respectively. Interestingly, the $\mathrm{Fe}(2)$ and $\mathrm{Fe}(1)$ or $\mathrm{Fe}(3)$ octahedrons are rotated $c a .90^{\circ}$ with respect to each 
other so that the methanol or $\left[\mathrm{Au}(2)(\mathrm{CN})_{2}\right]^{-}$terminal ligands, respectively, point almost perpendicularly out of the layers. These layers can also be described as the crossing of two chain systems, namely $-[\mathrm{Fe}(1)-\mathrm{Fe}(2)]_{n}-$ and $-[\mathrm{Fe}(2)-\mathrm{Fe}(3)]_{n}-$, forming an angle equal to $69.4(1)^{\circ}$. The layers perfectly superpose along [100] direction and the separation between two consecutive layers falls in the 5.5-6.5 $\AA$ range. However, a view of the structure along [111] direction shows that they are slipped 8.240(3) $\AA$ ( $a$ parameter) in the $x$ direction (Fig. 1 bottom). A remarkable consequence is that the dangling $[\mathrm{Fe}(1)-\mathrm{N}(2)-\mathrm{C}(2)-\mathrm{Au}(2)-\mathrm{C}(3)-\mathrm{N}(4)]$ moieties penetrate the $[\mathrm{Fe}(2)]_{4}$ rhombuses of the adjacent layers in such a way that the $\mathrm{N}(4)$ atoms of a particular layer, i.e. L(1), strongly interact via hydrogen bonding with the oxygen atoms $\mathrm{O}(1)$ belonging to the layers $\mathrm{L}(1 \pm 3)[\mathrm{N}(4) \cdots \mathrm{O}(1)=2.65(7) \AA] . \mathrm{L}(2)$ and $\mathrm{L}(3)$ interact in the same way with $\mathrm{L}(2 \pm 3)$ and $\mathrm{L}(3 \pm 3)$, respectively. From a supramolecular viewpoint the equivalent 2-D coordination polymers interact via hydrogen bonds to give a triple interpenetrated system of 3-D networks with the rare $\mathrm{NbO}$ topology (Fig. 2 top (left)). The total void space, located at $(0.0,0.5,0.5)$ (see Fig. 2c), is $18.1 \AA^{3}$ per unit cell volume (1601.01 $\AA^{3}$ ), which represents $1.1 \%$ of the unit cell. ${ }^{6}$

The geometrical proximity between the $\mathrm{Fe}(3)$ atom and the uncoordinated nitrogen atom $\mathrm{N}(4), \mathrm{Fe}(3)-\mathrm{O}(1) \mathrm{H}\left(\mathrm{CH}_{3}\right) \cdots \mathrm{N}(4)$ $\mathrm{C}(3)-\mathrm{Au}(2)-\mathrm{C}(2)-\mathrm{N}(2)-\mathrm{Fe}(2)$ provides a favourable pathway for a topochemical reaction to take place (Fig. 2a). Indeed, a new stable species (2) is formed after complete and rapid loss of methanol, which occurs in the temperature range $400-450 \mathrm{~K}$. The X-ray powder diffraction pattern (XRPD) recorded at $290 \mathrm{~K}$ after

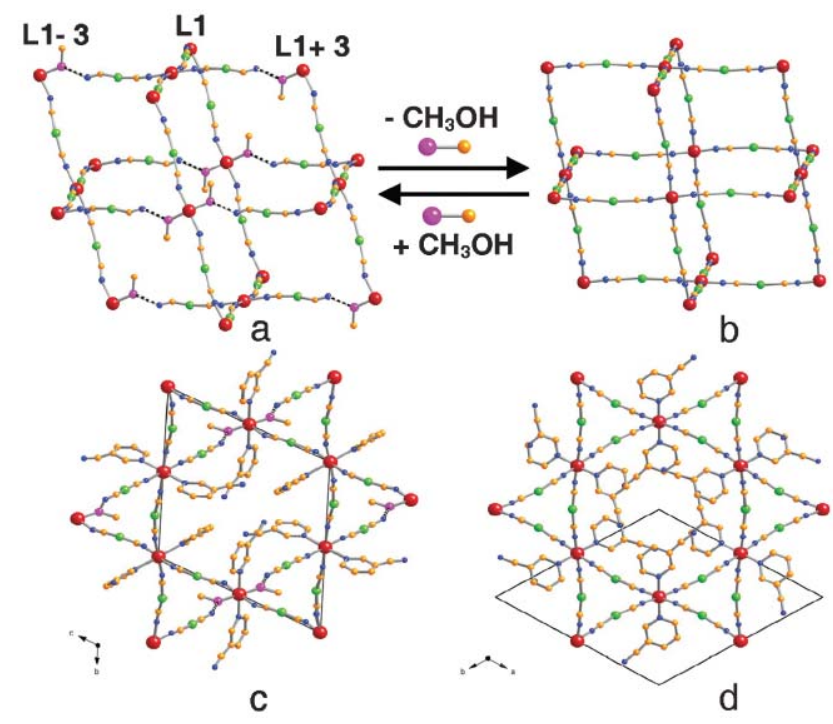

Fig. 2 Structural modifications during the crystalline-state ligand substitution $\mathbf{1} \leftrightarrow \mathbf{2}$ involving the concerted coordination/uncoordination of the terminal cyanide group and the methanol molecule. Top: (a) perspective view of three layers interconnected via hydrogen bonds represented as dotted lines (compound 1); (b) condensation of the three layers to form the new 3-D coordination polymer 2 with the $\mathrm{NbO}$ topology. Bottom: (c) and (d) show two perspective views of the coordination polymers $\mathbf{1}$ and $\mathbf{2}$ along the [001] and [100] directions, respectively, emphasizing the dramatic structural effects that the $\mathbf{1} \leftrightarrow \mathbf{2}$ transformation has particularly on the porosity of the networks (the solid lines represent the unit cell; code atom: red $(\mathrm{Fe})$, green $(\mathrm{Au})$, orange $(\mathrm{C})$, blue $(\mathrm{N})$, pink $(\mathrm{O})$. desolvation reveals the structural changes caused by the loss of the methanol molecule. This large structural modification affects the integrity of the single crystals of $\mathbf{2}$ precluding the in situ structure determination from single-crystal diffraction techniques. Interestingly, the XRPD pattern of $\mathbf{2}$ and that calculated from the previously reported single crystals of $\{\mathrm{Fe}(3-$ $\left.\mathrm{CNpy})_{2}\left[\mathrm{Au}(\mathrm{CN})_{2}\right]_{2}\right\} \cdot n \mathrm{H}_{2} \mathrm{O}(n<2 / 3)$ are virtually identical, indicating that they are the same compound (Fig. 3). A detailed description of the corresponding structure at 293 and $120 \mathrm{~K}$ and that of the isostructural $\left\{\mathrm{Fe}(3-\mathrm{CNpy})_{2}\left[\mathrm{Ag}(\mathrm{CN})_{2}\right]_{2}\right\} \cdot 2 / 3 \mathrm{H}_{2} \mathrm{O}$ are given in ref. 7 and 8 , respectively.

The loss of the coordinated methanol molecules and the concomitant coordination of the N(4) atom at the $\mathrm{Fe}(3)$ site involves a change from the triclinic $P \overline{1}$ space group to the trigonal $P-\overline{3}$ space group. ${ }^{7}$ Consequently, the rigid 2-D layers connected via hydrogen bonds convert into an even more rigid polymer made up of triple interpenetrated 3-D coordination networks, which preserve the same $\mathrm{NbO}$ topology (Fig. 2b). This process requires noticeable contraction of the space between the layers of $c a .2 .371 \AA$ and drastic reorientation of the aromatic rings, a fact that enables the formation of a hexagonal array of open channels (diameter $c a$. $7.5 \AA$ ) separated by ca. $9 \AA$. The total guest-accessible volume ${ }^{6}$ is $137.6 \AA^{3}$ per unit cell volume $\left(1514.3 \AA^{3}\right)$, which represents $9.1 \%$ of the unit cell. However, the accessible volume in the hexagonal channels, located at $(0.0,0.0,0.0)$, is $95 \AA^{3}$ and can accept small molecules (Fig. 2d). In fact strongly disordered molecules of water were found in $\left\{\mathrm{Fe}(3-\mathrm{CNpy})_{2}\left[\mathrm{Au}(\mathrm{CN})_{2}\right]_{2}\right\} \cdot n \mathrm{H}_{2} \mathrm{O}$. ${ }^{7}$

It is worth noting that a different crystal-to-crystal transformation was reported recently for the related coordination polymer $\left\{\mathrm{Fe}(\mathrm{pmd})\left(\mathrm{H}_{2} \mathrm{O}\right)\left[\mathrm{Au}(\mathrm{CN})_{2}\right]_{2}\right\} \cdot \mathrm{H}_{2} \mathrm{O}$ (pmd = pyrimidine), which exhibits the topology of the $\mathrm{CdSO}_{4}$. In that case the crystallinestate reaction involved reversible adsorption and release of vapour of water. In this reversible process the concerted reaction takes place between a non-coordinated nitrogen atom of a pyrimidine ligand and an iron(II) site which loses two axially coordinated water molecules. This reaction also involves the reversible transformation of the three interpenetrated $\mathrm{CdSO}_{4}$-like networks into a new non-interpenetrated 3-D net. ${ }^{5}$

Fig. 4 displays the $\chi_{\mathrm{M}} T$ product, where $\chi_{\mathrm{M}}$ is the magnetic susceptibility and $T$ is the temperature, for $\mathbf{1}$ and $\mathbf{2}$. Both compounds undergo an incomplete spin transition involving $30 \%$ of the iron atoms. The transition takes place without hysteresis at

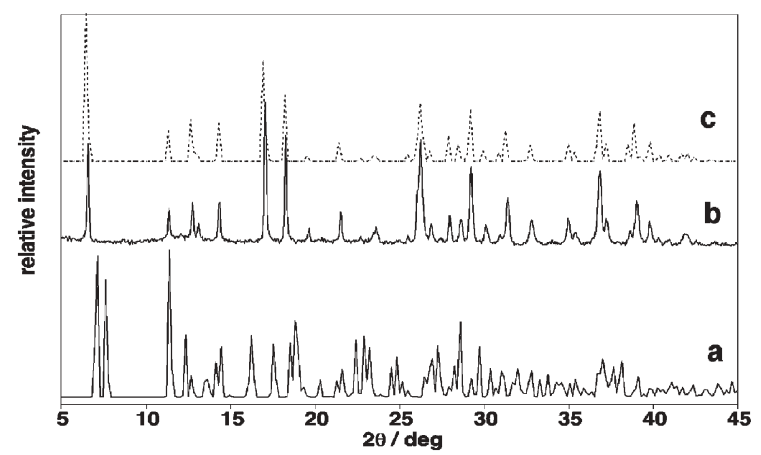

Fig. 3 (a) Calculated XRPD pattern of compound $\mathbf{1}$ before releasing the methanol molecule, (b) experimental XRPD pattern of 2, and (c) calculated XRPD pattern of $\left\{\mathrm{Fe}(3-\mathrm{CNpy})_{2}\left[\mathrm{Au}(\mathrm{CN})_{2}\right]_{2}\right\} \cdot n \mathrm{H}_{2} \mathrm{O}(n \leqslant 2 / 3)$ (broken line) from ref. 7 data. 


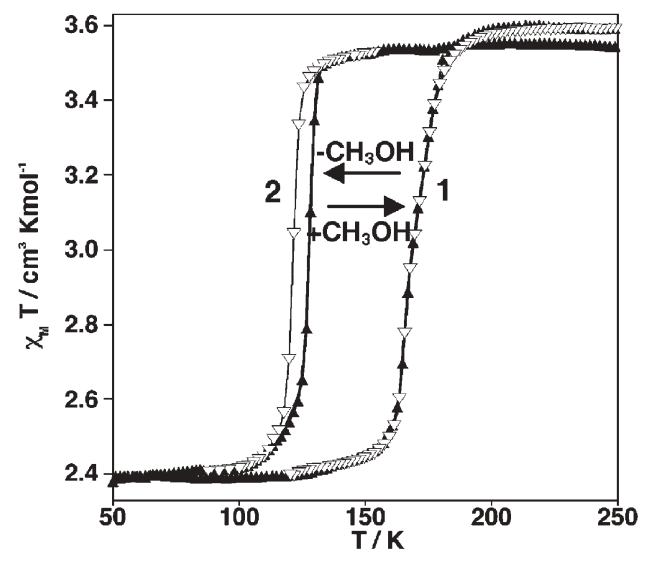

Fig. 4 Magnetic susceptibility measurements displaying the spin transition for $\mathbf{1}$ and $\mathbf{2}$.

$T_{\mathrm{c}}=169 \mathrm{~K}$ for 1 while it displays a hysteresis loop of $c a .6 \mathrm{~K}$ for 2 with $T_{\mathrm{c}}^{\text {down }}=121.5 \mathrm{~K}$ and $T_{\mathrm{c}}^{\text {up }}=127.8 \mathrm{~K}$. The $\mathbf{1} \rightarrow \mathbf{2}$ transformation is accompanied by a decrease of the critical temperature, $T_{\mathrm{c}}$, of $c a$. $44 \mathrm{~K}$. The occurrence of hysteresis in 2 indicates stronger cooperativity: better communication between the SCO building blocks and, consequently, more efficiency in transmitting the structural changes associated with the SCO. Stronger cooperativity in $\mathbf{2}$ also supports the idea that replacement of hydrogen bonds with more robust coordination links generates a more rigid framework. It is worth noting that the spin crossover behaviour of $\mathbf{2}$ and the previously observed one for $\{\mathrm{Fe}(3-$ $\left.\mathrm{CNpy})_{2}\left[\mathrm{Au}(\mathrm{CN})_{2}\right]_{2}\right\} \cdot n \mathrm{H}_{2} \mathrm{O}$ is identical as they correspond essentially to the same compound in agreement with the structural data. ${ }^{7}$ Interestingly, these structural data reveal the occurrence of only one crystallographically different Fe site in $\mathbf{2}$ at 293 and $120 \mathrm{~K}$. This result contrasts with the fact that only $30 \%$ of the Fe(II) atoms undergo SCO and suggests the existence of slightly different Fe sites which are probably averaged by the X-rays. In this respect it deserves pointing out that there are three asymmetric units per unit cell. This is not the case for $\mathbf{1}$ since it has three crystallographically distinct $\mathrm{Fe}$ sites. $\mathrm{Fe}(3)$ site is permanently $\mathrm{HS}$ while sites $\mathrm{Fe}(1)$ and $\mathrm{Fe}(2)$, which display the $\left[\mathrm{FeN}_{6}\right]$ chromophore, have practically identical averages of the $\mathrm{Fe}-\mathrm{N}$ bond distances and they are potentially SCO sites but obviously only one displays SCO. Unfortunately, any attempt to perform single crystal X-ray diffraction studies on $\mathbf{1}$ at temperatures $T \leqslant T_{\mathrm{c}}=169 \mathrm{~K}$ was unsuccessful. The $\mathbf{1} \rightarrow \mathbf{2}$ transformation converts the $\left[\mathrm{Fe}(3) \mathrm{N}_{4} \mathrm{O}_{2}\right]$ chromophore into a $\left[\mathrm{FeN}_{6}\right]$ chromophore. However, apparently, the expected increase of ligand field strength is not enough to induce $\mathrm{SCO}$ at the $\mathrm{Fe}(3)$ site.

Furthermore, when $\mathbf{2}$ is soaked in methanol, it recovers the magnetic behaviour and the XRPD pattern of 1 , which corroborate the reversibility of the process (see ESI) $\uparrow$ We have also confirmed the selective character of this process as $\mathbf{1}$ only forms from methanol solutions and no equivalent compound is obtained when $\mathrm{H}_{2} \mathrm{O}$, EtOH or $\mathrm{PrOH}$ is used as solvent. It is worth noting that the concerted coordination/uncoordination of the methanol molecule and the cyanide $\mathrm{N}(4)-\mathrm{C}(3)-\mathrm{Au}(2)$ moiety works like a molecular "lock keeper" opening $(\mathbf{1} \longrightarrow \mathbf{2})$ and closing $(\mathbf{2} \rightarrow \mathbf{1})$ the channels during the $\mathbf{1} \leftrightarrow \mathbf{2}$ transformation. This transformation changes the ligand field strength of the SCO iron(II) site modifying the $T_{c}$ and the cooperativeness of the spin transition.
We are grateful for financial assistance from the Spanish Ministerio de Educación y Ciencia (MEC) (project CTQ200403456/BQU). AG thanks to the Universitat Politécnica de València for a predoctoral fellowship.

\section{Notes and references}

* Synthesis: Single crystals of 1 were grown from a methanolic solution containing $\mathrm{Fe}\left(\mathrm{BF}_{4}\right)_{2} \cdot 6 \mathrm{H}_{2} \mathrm{O}(0.125 \mathrm{mmol}, 42.2 \mathrm{mg})$ and 3-CNpyridine $(0.25 \mathrm{mmol}, 26 \mathrm{mg})$ in $40 \mathrm{ml}$ to which was added a water solution $(2 \mathrm{ml})$ of $\mathrm{K}\left[\mathrm{Au}(\mathrm{CN})_{2}\right](0.25 \mathrm{mmol}, 72.04 \mathrm{mg})$. The resulting solution was stirred for $10 \mathrm{~min}$ and left at room temperature to evaporate under an argon stream. The crystals were separated one week later. Yield $c a$. 65\%. Elemental analysis (\%) calcd for $\mathrm{C}_{16.66} \mathrm{H}_{10.66} \mathrm{~N}_{8} \mathrm{O}_{0.66} \mathrm{Au}_{2} \mathrm{Fe}$ : C 25.53, H 1.36, N 14.29; found: C 25.60, H 1.40, N 14.43.

Compound $\mathbf{2}$ was obtained from the controlled thermal desolvation of 1 using a TGA Mettler Toledo TGA/SDTA 851e system. The loss weight in the temperature region $400-450 \mathrm{~K}$ is $2.72 \%$ and corresponds to the release of 0.66 molecules of $\mathrm{CH}_{3} \mathrm{OH}$ per iron atom. Elemental analysis (\%) calcd for $\mathrm{C}_{16} \mathrm{H}_{8} \mathrm{~N}_{8} \mathrm{Au}_{2} \mathrm{Fe}$ : C 25.19, H 1.05, N 14.70; found: C 25.03, H 1.15, N 14.75. Compound 2, $\left\{\mathrm{Fe}(3-\mathrm{CNpy})_{2}\left[\mathrm{Au}(\mathrm{CN})_{2}\right]_{2}\right\} \cdot n \mathrm{H}_{2} \mathrm{O}$, can also be synthesised directly as single crystals. Crystallogenesis, crystal structures at 293 and $120 \mathrm{~K}$ and magnetic behaviour are given in ref. 7 .

$\S$ Crystal data for $\mathbf{1}: \mathrm{C}_{25} \mathrm{H}_{16} \mathrm{~N}_{12} \mathrm{O}_{1} \mathrm{Au}_{3} \mathrm{Fe}_{1.5}, M_{\mathrm{r}}=1175.17$, triclinic, $P \overline{1}, a=$ 8.240(3), $b=14.790(4), c=14.532(6) \AA, \alpha=112.694(11), \beta=95.567(13), \gamma=$ $97.10(2)^{\circ}, V=1601.0(9) \AA^{3}, Z=2, \rho_{\text {cald }}=2.438 \mathrm{~g} \mathrm{~cm}^{-3}, \mu=14.404 \mathrm{~mm}^{-1}$, final $R_{1}(I>2 \sigma(I))=0.0959, w R_{2}$ (all data) $=0.2690, \mathrm{GOF}=1.136$.

The diffraction data was measured on a Nonius Kappa-CCD single crystal diffractometer using Mo $\mathrm{K} \alpha(\lambda=0.71073 \AA)$. A multi-scan absorption correction was performed but not applied. The absorption correction was found to have no significant effect on the refinement results. The structures were solved by direct methods using SHELXS-97 and refined by full-matrix least squares on $F^{2}$ using SHELXL-97. ${ }^{9}$ A rigid body for the 3-CNpy ring was applied and the ring position was refined. CCDC 297493. For crystallographic data in CIF or other electronic format see DOI: 10.1039/b606434e. These data can be obtained free of charge from the Cambridge Crystallographic Data Centre via http://www.ccdc.cam. ac.uk/data_request/cif.

1 (a) C. Janiak, Dalton Trans., 2003, 2781; (b) S. L. James, Chem. Soc. Rev., 2003, 32, 276; (c) S. Kitagawa, R. Kitaura and S. Noro, Angew. Chem., Int. Ed., 2004, 43, 2334; (d) J. L. C. Rowsell and O. M. Yaghi, Angew. Chem., Int. Ed., 2005, 44, 4670.

2 (a) J. A. Real, E. Andrés, M. C. Muñoz, M. Julve, T. Granier, A. Bousseksou and F. Varret, Science, 1995, 268, 265; (b) G. J. Halder, C. J. Kepert, B. Moubaraki, K. S. Murray and J. D. Cashion, Science, 2002, 298, 1762.

3 (a) J. A. Real, A. B. Gaspar and M. C. Muñoz, Dalton Trans., 2005, 2062; (b) Spin Crossover in Transition Metal Compounds, ed. P. Gütlich and H. A. Goodwin, Top. Curr. Chem., vol. 233-235, Springer-Verlag, Berlin, 2004; (c) J. A. Real, A. B. Gaspar, V. Niel and M. C. Muñoz, Coord. Chem. Rev., 2003, 236, 121; (d) O. Kahn and C. J. Martinez, Science, 1998, 279, 44.

4 (a) K. Biradha and M. Fujita, Angew. Chem., Int. Ed., 2002, 41, 3392; (b) K. Biradha, Y. Hongo and M. Fujita, Angew. Chem., Int. Ed., 2002, 41, 3395; (c) M. P. Suh, J. W. Ko and H. J. Choi, J. Am. Chem. Soc., 2002, 124, 10976; (d) S. Takamizawa, E. Nakata, H. Yokoyama, K. Mochizuki and W. Mori, Angew. Chem., Int. Ed., 2003, 42, 4331; (e) B. Rather and M. J. Zaworotko, Chem. Commun., 2003, 830; (f) T. K. Maji, K. Uemura, H. C. Chang, R. Matsuda and S. Kitagawa, Angew. Chem., Int. Ed., 2004, 43, 3269; $(g)$ E. Y. Lee and M. P. Suh, Angew. Chem., Int. Ed., 2004, 43, 2798; (h) D. N. Dybtsev, H. Chun and K. Kim, Angew. Chem., Int. Ed., 2004, 43, 5033.

5 V. Niel, A. L. Thompson, M. C. Muñoz, A. Galet, A. E. Goeta and J. A. Real, Angew. Chem., Int. Ed., 2003, 42, 3760.

6 A. L. Spek, PLATON, a multipurpose crystallographic tool, Utrecht University, The Netherlands, 2001.

7 A. Galet, M. C. Muñoz, V. Martínez and J. A. Real, Chem. Commun., 2004, 2268

8 A. Galet, V. Niel, M. C. Muñoz and J. A. Real, J. Am. Chem. Soc., 2003, 125, 14224

9 G. M. Sheldrick, SHELXS97 and SHELXL97. University of Göttingen, Germany. 1997. 